\title{
Important Developments of Leisure Education in American Public Schools: What Can We Learn From Them? 美國學校的休閒教育:他山之石
}

\author{
Toh Kian Lam \\ Department of Physical Education, \\ Hong Kong Baptist University, HONG KONG
}

卓建南

香港浸會大學體育學系

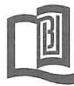

\begin{abstract}
The notion of leisure education can trace its roots far back to Ancient Greece. The aim of leisure education is not to increase the number of subjects offered by the schools, but rather to infuse the values of leisure into the existing subjects. The objective is to guide the students in making good use of their leisure, which in fact is one of the secondary school curriculum aims. Besides presenting some of the important developments of leisure education in American public schools, this paper also highlights some of the reasons why leisure education fails in the United States. These problems are relevant to us especially if we want to make leisure education in Hong Kong a reality one day.
\end{abstract}

\section{摘要}

休閒教育的起源可追溯到古希臘時代。休閒教育的目的不在於增加學校的科目，而是將休閒的價值溶入目前學校既有的 科目中, 引導學生善用閒暇時間, 這也正是香港的教育目標之一。美國學校的休閒教育可說是失敗的。本文首先提出休閒教育 在美國的一些重要發展, 然後舉出一些造成他們失敗的可能原因, 若是有朝一日休閒教育在本港萌芽, 那麼我們就不得不重視 這些我們也可能面對的問題。

\section{Introduction}

In her book, The Overworked American, Schor (1991) revealed that Americans in fact have fewer leisure hours, that "the development of capitalism involved a tremendous expansion of human effort. People began to work longer and harder" (p. 16). However, more people hold the opposite view. They are convinced that the technological advancement and automation have reduced our working hours in general. Regardless of which camp one belongs to, one truth is common, i.e., the concept of worthy use of leisure has not yet been ingrained into people's minds.

There is no doubt that leisure education is of paramount importance in today's society. The notion of leisure education in fact can trace its roots far back to Ancient Greece. Such famous philosophers as Aristotle and Socrates had all indicated the values of leisure education as an apex component of a complete education. For instance, Aristotle wrote that "we should be able not only to work well but to use leisure well; for, as I repeat once more, the first principle of all action is leisure. Both are required, but leisure is better than work and is its end..." (cited in Staley \& Miller, 1972, p. 10). In discussing some new goals for education in a democratic society, John Dewey (1916) raised the importance of education for leisure by stating that "a new concept of the uses of leisure has to be created; boys and girls need to be instructed so that they can discriminate between the enjoyments that enrich and enlarge their lives and those which degrade and dissipate" (cited in Lies, 1933, p. 272). It was however, not until 1918 when the need for leisure education had been put forth officially. "Worthy use of leisure" was one of the "Seven Cardinal Principles of Secondary education" suggested by the Commission on the Reorganization of Secondary Education. Many educators had also written books, (e.g., Kraus, 1964; Mundy $\&$ Odum, 1979), pertaining to leisure education. In 1977, National Recreation and Park Association (NRPA) even published a curriculum for grades K-12 called "Kangaroo Kit". Leisure education seemed to start to gain its momentum. It did not. After an extensive review of related literature, it was discovered that there was evidence expressing the importance of leisure education but nothing much had been accomplished. 
Sivan (1996) proposed that schools in Hong Kong should go beyond the extracurricular activities and non-examinable subjects and should fully utilize the potential of each subject area of the school for infusing the values of leisure. Even though the idea was not new, it seems relevant because it echoed one of the curriculum aims of Hong Kong Secondary schools - to develop students' cultural and recreational interests and to guide them in making good use of their leisure (Curriculum Development Institute, 1999). In order to achieve this aim, leisure education seems necessary. With regard to how to realize the idea, however, it still requires further study and scrutiny. The purposes of this paper include presentation of some of the important developments in leisure education in the United States and illustration of some of the reasons why the American schools were unable to make leisure education a success. It is hoped that lessons will be learnt from their experience should leisure education become a reality in Hong Kong.

This paper begins with an introduction of what leisure education is and is followed by presenting some prominent advocates of worthy use of leisure. Reasons for failing to infuse leisure education into the public school curriculum were the results of the author's personal interviews with some of the scholars in the United States who are all well respected for their continuous involvement in leisure education. One caveat when interpreting this article is that leisure education for people with disabilities is not the focus of this article. Readers who are interested in knowing more about that particular area of study may refer to Bullock and Mahon's (1997) "Introduction to recreation services for people with disabilities" and Dattilo and Murphy's (1991) "Leisure education program planning: A systematic approach".

\section{What is Leisure Education?}

According to Mobley (1975), leisure education can best be defined in terms of a process. It is a "process through which an individual develops an understanding of himself, leisure, and the relationship of leisure to the quality of his individual life and the fabric of the society" (p. 11). NRPA (1977), also views leisure education as a process whereby people:

- recognize that leisure is an avenue for personal satisfaction and enrichment;

- are aware of the many valuable leisure opportunities available;

- understand the significance of leisure to society;

- appreciate our natural resources and their relationship to leisure and life quality;

- develop attitudes, knowledge, and skills that will assist in making leisure satisfying;

- are able to make responsible decisions regarding their own leisure; and

- are able to act on their leisure interests and needs.
In essence, leisure education is a process in which individuals are educated to better and wisely use their leisure so as to achieve their ultimate goal, i.e., the improvement of their quality of life. This process involves changes or improvements in attitudes, knowledge, skills, and ultimately, leads to behavioral change.

\section{Worthy Use of Leisure-Some Prominent Advocates}

As mentioned earlier, many prominent figures advocated for the worthy use of leisure but little was accomplished especially in the American public schools. This section provides some examples of prominent educators and leisure educators who all believe in leisure education.

\section{Educators}

In his volume entitled "Education: Intellectual, Moral, and Physical" (cited in Painter, 1970), Spencer (1860) stressed that in order to live completely, schools should teach the students how to treat their body and mind, manage their affairs, bring up a family, behave as a citizen, and utilize all those resources of happiness which nature supplies. He indicated that the first step obviously should be to classify, in the order of importance, the leading kinds of activity which constitute human life. Those include:

1. activities which directly minister to self-preservation.

2. activities which, by securing the necessaries of life, indirectly minister to self-preservation.

3. activities which have for their end the rearing and disciplining of off-spring.

4. activities which are involved in the maintenance of proper social and political relations.

5. miscellaneous activities which make up the leisure part of life devoted to the gratification of tastes and feeling.

Under such circumstances as country urbanization, industrialization, and increased immigration, the National Education Association, through the Commission on Reorganization of Secondary Education (Willis, Schubert, Bullough, Kridel, \& Holton, 1994), created a statement of Seven Cardinal Principles in 1918. The Principles were intended to broaden the curriculum not only to include the traditional academic subjects but more importantly, to encompass all of life's experiences. The seven areas of life for secondary curriculum include: 1 . health, 2. command of fundamental processes, 3. worthy home-membership, 4. vocation, 5. civic education, 6 . worthy use of leisure, and 7. ethical character

Each of the seven principles may be considered having significance to leisure education. However, the "worthy use of leisure" had the most definite and direct relevance. According to the commission, education for the worthy use of leisure is 
important because the unworthy use of leisure could impair health, lessen vocational efficiency, destroy civic mindedness, and disrupt home life. On the other hand, if worthily used, leisure could recreate individual's powers, enlarge and enrich her/his life, and subsequently make her/him better able to meet all her/his responsibilities.

In one of his syndicated articles in 1926, Glenn Frank, President of the University of Wisconsin (cited in Lies, 1933), stated that if he were writing the history of a people and was concerned to discover and to distill in my pages their essential spirit, I should, after I had caught the story of their statesmen and their serfs, of their captains of arms and their captains of industry, take ample time off to shadow them in their off hours while they were at play. If I found them selfsufficient and resourceful in their use of leisure, I would not worry about the external state of their civilization at the moment. I would know that the inner sources of their power were rich with unexploited possibilities. (p. 272)

However, he stated that if he found people "helpless in the face of an idle hour" he "would know that the inner sources of their power were running dry" and that their "promise of creative contributions to the future would have to be discounted" (p. 272). It is obvious that President Frank was actually trying to create a relationship between a person's contributions to the future world and her/his ability to worthily utilize her/his leisure.

Two educators, Nicholas M. Butler, President of Columbia University in 1924, who favored education for leisure over the prevailing emphasis on vocational guidance, and Franklin Bobbitt, who presented a paper entitled "The Trend of the Curriculum" in the Second Yearbook of the Department of Superintendence (1924) that emphasized on having a program that would prepare the students in the schools for the worthy use of their spare time, had a similar fate as President Frank - their dreams did not materialize.

In the "Third Yearbook of the John Dewey Society" (1939), Hollis Caswell presented a paper entitled "Developing the Design of the Curriculum". He indicated that the growth of invention and technology had greatly extended the hours of leisure. It was his belief that schools should guide students to worthily utilize their leisure. In addition,

... special provision should be made for creative and recreational activities, particularly in the arts, in games, and in hobbies. It is the right of every individual to have wide opportunities to cultivate his individual interests and aptitudes in these areas, and curriculum designers must guard against the tendency to slight them. (p. 427)
In the Spring of 1944, the Educational Policies Commission issued its first statement on educational needs. The statement contained ten "imperatives in educational needs of youth". The commission believed that all youth need:

1. to develop salable skills and understandings and attitudes that make the worker an intelligent and productive participant in economic life.

2. to develop and maintain good health and physical fitness.

3. to understand the rights and duties of the citizen of a democratic society and competence in the performance of obligations as a citizen.

4. to understand the significance of the family and of the conditions conducive to successful family life.

5. to know how to purchase and use goods and services, of the values received by the consumer, and of the economic consequences.

6. to understand the methods of science, the influence of science on human life, and the main scientific facts.

7. opportunities to develop capacities to appreciate beauty in literature, art, music, and nature.

8. to be able to use leisure time well and budget it wisely, balancing activities that yields satisfactions with those that are socially useful.

9. to develop respect for other persons, insight into ethical values and principles, and ability to live and work cooperatively with others.

10. to grow in their ability to think rationally, to express their thoughts clearly, and to read and listen with understanding.

In 1966, a special commission appointed by J. Win Pagne, President of the American Association of School Administrators (AASA), identified nine imperatives in education after two years of study. The imperatives include:

1. to make urban life rewarding and satisfying.

2. to prepare people for the world of work.

3. to discover and nurture creative talent.

4. to strengthen the moral fabric of society.

5. to deal constructively with psychological tensions.

6. to keep democracy working.

7. to make intelligent use of natural resources.

8. to make the best use of leisure time.

9. to work with other peoples of the world for human betterment.

The imperatives "are points at which the educational program must be revised and reshaped to meet the needs of the times. To the extent that they are useful to school administrators and other educational leaders in meeting and dealing with crucial educational problems they will have served their purpose", stressed Forrest E. Conner, the executive secretary of AASA. The commission believed that the schools' efforts might be more rewarding if 
the values of leisure were fitted into existing patterns of organization and the framework of the instructional program. In so doing, not only would the schools instill in the minds of our young people an awareness of the importance of leisure time but also cultivate values, habits, and practices that would lead them to the better use of leisure time. The commission had a strong belief that English, Science, Music, Graphic Arts, Vocational Education, Physical Education, Home Economics, and Student Government and other activities could all be used to cultivate the values of the worthy use of leisure.

\section{Leisure Educators}

A number of leisure educators also provide support for leisure education. In his article entitled "The Schools Enriching Leisure", J. E. Morgan (1928) declared that the schools can assist in enriching leisure by:

1. introducing young people to a wide range of life interests;

2. teaching the use of books and libraries and developing wholesome reading appetites closely related to each of the great objectives of education and life;

3. developing appreciation of fine music and skill in singing, playing, and dancing;

4. having children participate in games and sports which may be easily continued in after years;

5. providing experience in pleasant social life through school activities and clubs;

6. cultivating in children a love of the out-of-doors - appreciation of flowers, animals, landscape, sky, and stars;

7. giving children an opportunity to develop hobbies in various creative fields - gardening, mechanics, applied arts, fine arts, architecture, city planning;

8. making the school and its play fields the center and servant of a wholesome and satisfying neighborhood life; and

9. calling attention to various recreational agencies and the values which they serve - theaters, concerts, libraries, radio, periodicals and newspapers, museums, parks, playgrounds, travel.

In their book entitled "Mass Leisure", Larrabee and Meyersohn (1958) also expressed their concerns on education and leisure. They indicated that education has not prepared individuals for the sudden onrush of leisure as a version of technological unemployment. In addition, their education has not prepared them for it and the creation of new wants at their expense moves faster than their ability to order and assimilate these wants.

In 1975, NRPA received a two-year grant from Lilly Endowment Inc., of Indiana to develop a leisure education model. The resulting project was titled the Leisure Education Advancement Project (LEAP). The main purpose of the LEAP was to assist public schools in infusing the values of leisure into existing subjects for grades K-12. LEAP was not advocating an additional content area but instead, leisure education was designed to be infused into existing school subjects. The LEAP project however, did not survive long after the grant had expired. Most of the subjects in today's public schools still remain unchanged, with very little, if not none, emphasis on the values of leisure.

From the above illustrations, it is clear that leisure education is not doing well in American schools, or else the same issue would not be brought up repeatedly by so many people. What, then, are the reasons for the failure?

\section{Reasons for the Failure}

After the emergence of the Seven Cardinal Principles of Secondary Education in 1918, among the many advocates for the worthy use of leisure, the most prominent undertaking was by the NRPA (1977) of whom advocated the infusion of the values of leisure into existing subjects in the public schools. However, its effort resulted in no success even though a specific curriculum (Kangaroo Kit) had been developed and readily for use. What actually happened? Odum and Lancaster conducted a national survey in 1976 to determine the state of leisure education within public school systems in the United States. The following are selected conclusions drawn from their study.

- There is much misunderstanding both as a concept and as a process of leisure education.

- There is an emphasis on leisure "activities" in some states, but few states have made any attempt to focus on attitudes and values related to leisure.

- Some states viewed leisure education as being outside the role of the schools, especially in light of the "back to basics" movement, although philosophically they may be supportive of the concept (Reardon \& Mundy, 1984).

Although the survey was a bit outdated, it still appears to reflect the current status of leisure education within education systems (Reardon \& Mundy, 1984). Below are a few more reasons for the failure of leisure education in American schools.

Importance of leisure unknown - A majority of people, including the teachers, administrators, and parents are still not aware of the importance of leisure. Most of them still cannot accept the notion that a leisure society is emerging. To them, work is still the center of their life. In addition, they all "think" that they know what to do with their leisure. In reality, however, they do not. People need to be educated and taught how important leisure is and made known the ways to wisely utilize their leisure. Moreover, since the teachers and principals did not have related education before, it would be difficult for them to apprehend 
why leisure education is so necessary. Under such circumstances, what can they impart to their students?

"Wrong" attitudes and lack of comprehension of the concept of leisure - Mundy and Odum (1979) indicated that attitudes were the most formidable barrier to leisure education. For examples, leisure education is not the "3 R's", teachers showed limited interest, negative feelings and concerned about the already crowded curriculum, and parents expressed fears of potential physical hazards. Jewell (1978) indicated that vast majority of people lack comprehension of the concept of leisure. The "society work ethic carries over into private life and prevents leisure from being seen as a positive value" (p. 12). A lot of people also equate leisure education with physical education without understanding the real meaning of leisure.

Shortage of dedicated professionals - There is a lack of instigation from the recreation profession. They have not done enough to sell the importance of leisure. It is a task that could not be done in a short period of time. More dedicated people are required.

Inflexilbility of school system - Since public schools are supported by tax monies, no one is willing to "risk" spending money on teaching leisure. Because of the mind-set that education should teach students how to prepare for work, teaching things related to leisure sounds ridiculous and unproductive. Again, due to the lack of knowledge in leisure education, principals and teachers believe that they cannot afford to add another subject, while, in reality, the values of leisure can be infused into existing subjects.

Teachers not sophisticated - For those teachers, although not many, who have some knowledge in leisure, they do not seem sophisticated enough to incorporate the values of leisure into their responsible subject(s), even though there are guidelines such as the LEAP Kangaroo Kit produced by NRPA. More teachers who have the proper attributes and who have been educationally prepared for the task are required.

Budget constraint - Although the government has put money in the public park and recreation system, it still has not spent money on teaching the values of leisure in the public schools. Without necessary financial support, there is no way that the schools could do anything. On the other hand, most effort became futile because of inadequate funding for a particular project. For instance, once the two-year grant had expired, the LEAP project stopped and no one was "there" to monitor its progress and to provide further momentum for a success.

\section{Discussion and Conclusion}

Looking at the reasons for the failure, the reality is obvious. More than eighty years after the emergence of the "Seven Cardinal Principles of Secondary Education", there is still not much progress within the schools for leisure education. Worse still, the America 2000: An Education Strategy (US Department of Education, 1991) that puts forth six goals (later extended to eight goals) to be accomplished by the American schools by the year 2000, shows no sign of emphasizing leisure education. Neither has it been discussed between the President and all 50 Governors in their Latest "Summit on Education" in March, 1996 (Riechman, 1996). Would the same mistakes be committed by us should leisure education become a reality?

Education should equip the individual to secure from his leisure the re-creation of body, mind, and spirit, and the enrichment and enlargement of his personality.... One of the surest ways in which to prepare pupils worthily to utilize leisure in adult life is by guiding and directing their use of leisure in youth. The school should, therefore, see that adequate recreation is provided both within the school and by other proper agencies in the community. The school, however, has a unique opportunity in this field because it includes in its membership representatives from all classes of society and consequently is able through social relationships to establish bonds of friendship and common understanding that can not be furnished by other agencies.... (Willis et al., 1994, p. 236)

Schools have a unique opportunity to guide and direct youth in their use of leisure. However, having the capability to do something does not necessarily imply actual doing. The road to guiding the students in making good use of their leisure would not be a smooth one. Every school has already had too many things to worry about, e.g., students' academic performances, the problems accompanied by the arrival of new immigrant students, and youth gang, just to name a few. Nevertheless, the situation in Hong Kong would be better than in the US mainly because of the difference in administrative structure. So long as the government decides to go ahead with leisure education, schools would have to comply.

However, the preceding reasons for the failure of leisure education in the US are very relevant to us. Those problems need to be tackled accordingly before we can think of implementing leisure education in schools. General public need to be educated about the importance and benefits of leisure. The mind-set of "leisure is unproductive" should be corrected. In-service training 
on how to infuse the values of leisure into the existing subjects is necessary for the teachers and principals. Since the training of leisure professionals is vital to the success of leisure education, universities that provide training in physical education and recreation such as Hong Kong Baptist University can play an important role. The university's education department can also contribute. In addition, nothing much could be achieved if there is no funding. Therefore, government should play an active role by allocating enough financial resources to make leisure education a success.

Leisure education is not just a slogan. Neither is it merely a lofty goal. As long as all parties involved play their parts, it is very possible to realize this important aim of education.

\section{References}

American Association of School Administrators (1966). Imperatives in education. Washington, DC: AASA.

Bullock, C. C., \& Mahon, M. J. (1997). Introduction to recreation services for people with disabilities. Champaign, IL: Sagamore Publishing.

Curriculum Development Institute (1999). Curriculum aims across levels - secondary [On-line]. Available: http://www.info.gov. hk/ed/subject/cdi/cdicas.htm.

Dattilo, J., \& Murphy, W. D. (1991). Leisure education program planning: A systematic approach. State College, PA: Venture Publishing, Inc.

Department of Superintendence (1924). Second yearbook: The elementary school Curriculum. Washington, DC: National Education Association of the United States.

Educational Policies Commission (1944). Education for all American youth. Washington, DC: National Education Association of the United States.

Jewell, D. L. (1978). Aristotle said it first. ERIC. (Indiana University Microfiche No. ED 219500).

Kraus, R. (1964). Recreation and the schools. New York, NY: The Macmillan Company.

Larrabee, E., \& Meyersohn, R. (1958). Mass Leisure. Glenwe, IL: The Free Press.
Lies, E. T. (1933). The new leisure challenges the schools. Washington, DC: McGrath Publishing Company.

Mobley, T. (1975). Leisure education and the quality of life. In J. Mundy \& F. C. Cannon (Eds.), Leisure education and the quality of life (pp. 8-12), proceedings of the First National Leisure Education Conference, Tallahassee, FL.

Morgan, J. E. (1928). The schools enriching leisure. Journal of the National Education Association, 17(7), 197-199.

Mundy, J., \& Odum, L. (1979). Leisure education: Theory and practice. New York, NY: John Wiley \& Sons Inc.

National Recreation and Park Association (1977). Kangaroo kit: Leisure education curriculum guidelines. Arlington, VA: NRPA.

Painter, F. V. N. (1970). Great pedagogical essays. New York, NY: AMS Press Inc.

Reardon, R. \& Mundy, J. (1984). Career education and leisure education: Towards a K-12 life/development synthesis. Journal of Career Development, 11(2), 110-118.

Riechman, D. (1996, 3/28). Governors take actions on the education. Indiana Daily Students, Bloomington, IN.

Schor, J. B. (1991). The overworked American: The unexpected decline of leisure. USA: BasicBooks.

Sivan, A. (1996). Current model for leisure education in educational systems. In F. H. Fu \& P. C. Chan (Eds.), Recreation, sport, culture \& tourism for the $21^{\text {st }}$ century (pp. 192202). Hong Kong: Hong Kong Baptist University.

Staley, E. J., \& Miller, N. P. (1972). Leisure and the quality of life. Washington, DC: AAHPER Publication.

The John Dewey Society (1939). Third yearbook: Democracy and the curriculum. New York, NY: Appleton-Century Company.

U.S. Department of Education (1991). American 2000: An education strategy. Washington, DC: U.S. Government Printing Office.

Willis, G., Schubert, W. H., Bullough Jr., R. V., Kridal, C. \& Holton, T. (1994). The American curriculum: A documentary history. Westport, CT: Praeger Publishers. 